\title{
The German SUCCESS C Study - The First European Lifestyle Study on Breast Cancer
}

\author{
Brigitte Rack $^{\mathrm{a}} \quad$ Ulrich Andergassen ${ }^{\mathrm{a}} \quad$ Julia Neugebauer $^{\mathrm{a}} \quad$ Jessica Salmen $^{\mathrm{b}} \quad$ Philip Hepp $^{\mathrm{b}}$ \\ Harald Sommer $^{a} \quad$ Werner Lichtenegger $^{c}$ Klaus Friese $^{a} \quad$ Matthias W. Beckmann $^{d}$ \\ Dagmar Hauner $^{\mathrm{e}}$ Hans Hauner ${ }^{\mathrm{e}}$ Wolfgang Janni ${ }^{\mathrm{b}}$
}

aLudwig-Maximilians-University München, Frauenklinik, Campus Innenstadt, München,

${ }^{b}$ Frauenklinik, Klinikum der Heinrich-Heine-Universität Düsseldorf,

'Frauenklinik des Universitätsklinikums Charité Campus Virchow-Klinikum Berlin,

'Universitätsfrauenklinik Erlangen,

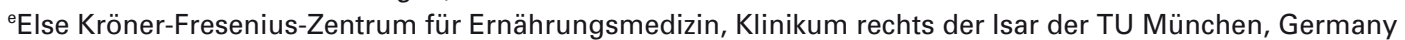

\section{Keywords}

Breast cancer - Obesity - Lifestyle intervention - Weight loss - Physical activity - Prognosis - Disease recurrence . Overall survival

\section{Summary}

Cohort trials have shown evidence that obesity and a low level of physical activity are not only associated with a higher risk of developing breast cancer, but also with an increased risk for recurrence and reduced survival in breast cancer patients. The SUCCESS $C$ study is the first European trial to evaluate the effect of an intensive lifestyle intervention program on disease-free survival in women with early breast cancer and to examine the predictive value of selected biomarker candidates. A total of 3,547 women with early-stage, Her2/neu-negative breast cancer will be included. The first randomization will compare disease-free survival in patients treated with either 3 cycles of FEC (epirubicine, fluorouracil, cyclophosphamide), followed by 3 cycles of docetaxel or 6 cycles of docetaxel-cyclophosphamide, and thus assess the role of anthracycline-free chemotherapy. The second randomization compares disease-free survival in patients with a body mass index of $24-40 \mathrm{~kg} / \mathrm{m}^{2}$ receiving either a telephone-based individualized lifestyle intervention program aiming at moderate weight loss or general recommendations for a healthy lifestyle alone. In addition, the study will evaluate the predictive role of cancer-associated and obesity-related biomarkers for the prediction of disease recurrence and survival. This SUCCESS C trial will provide valuable information on the effects of a lifestyle intervention program on the prognosis of early breast cancer patients.

\section{Schlüsselwörter}

Mammakarzinom - Adipositas - Lebensstilintervention . Gewichtsreduktion · Körperliche Aktivität · Prognose, Rezidiv · Gesamtüberleben

\section{Zusammenfassung}

Aktuelle Studien deuten darauf hin, dass Adipositas und ein Mangel an körperlicher Aktivität nicht nur mit einem erhöhten Risiko assoziiert sind, an einem Mammakarzinom zu erkranken, sondern auch nach der Erkrankung mit einer gesteigerten Rezidivrate und Mortalität einhergehen. Die SUCCESS C-Studie ist die erste europäische Studie, die den Einfluss eines intensivierten Lebensstilinterventionsprogramms auf das krankheitsfreie Überleben von Frauen mit frühem Mammakarzinom untersucht. Außerdem werden ausgewählte Biomarker getestet. Insgesamt werden 3.547 Frauen mit frühem, Her2/neu-negativen Mammakarzinom eingeschlossen. In der ersten Randomisation wird das krankheitsfreie Überleben unter einer Therapie mit entweder 3 Zyklen FEC (Epirubicin, Fluorouracil, Cyclophosphamid), gefolgt von 3 Zyklen Docetaxel oder 6 Zyklen Docetaxel-Cyclophosphamid verglichen, und damit die Rolle einer anthrazyklinfreien Chemotherapie in diesem Kollektiv geprüft. Die zweite Randomisation vergleicht das krankheitsfreie Überleben von Patientinnen mit einem Body Mass Index von $24-40 \mathrm{~kg} / \mathrm{m}^{2}$, die entweder ein telefonbasiertes Lebensstilinterventionsprogramm mit dem Ziel einer moderaten Gewichtsabnahme oder lediglich allgemeine Informationen für eine gesunde Lebensführung erhalten. Zusätzlich zur klinischen Fragestellung werden brustkrebs- oder adipositasassoziierte Biomarker auf ihre prognostische und prädiktive Wertigkeit hin geprüft. Die SUCCESS C-Studie wird wertvolle Informationen zur Effektivität eines Lebensstilinterventionsprogramms zur Prognoseverbesserung bei Mammakarzinompatientinnen liefern.

\section{KARGER}

Fax +497614520714

Information@Karger.de

www.karger.com
(C) 2010 S. Karger GmbH, Freiburg

Accessible online at:

www.karger.com/brc 


\section{Introduction}

Breast cancer is the most frequent malignancy in women of the industrialized Western hemisphere. In 2008, it was estimated that worldwide 1.38 million women were diagnosed with breast cancer, accounting for around a 10th (10.9\%) of all new cancers and nearly a quarter $(23 \%)$ of all female cancer cases [1]. In recent years, a decrease in mortality has been observed, which is attributed to early detection through screening programs and improved treatment efficacy. However, breast cancer incidence has been increasing for many years in economically developed countries. A substantial proportion of these breast cancers are thought to be associated with internal and external estrogen exposure, related to age at menarche and menopause, parity, duration of breastfeeding, and use of contraceptives and hormone replacement therapy. In addition to these well known risk factors, there is growing evidence for the influence of non-reproductive lifestyle factors. Several cohort studies have shown an increased risk for breast cancer associated with obesity, alcohol consumption, and low physical activity. Large prospective epidemiological studies show an association between obesity and breast cancer. In the Million Women Study, increasing body mass index (BMI) was associated with a significant increase in the risk of several cancer types, among them endometrial cancer, adenocarcinoma of the esophagus, kidney cancer, breast cancer in postmenopausal women, and colorectal cancer in premenopausal women [2]. Overweight postmenopausal women were observed to have a $10-20 \%$ increased risk of breast cancer, and obese postmenopausal women a $30 \%$ increased risk, while obese premenopausal women show a $20 \%$ risk reduction. In contrast, obesity is associated with poor prognosis both in pre- and postmenopausal breast cancer patients $[3,4]$. Changes in hormone metabolism, especially higher levels of circulating estrogens through increased aromatase activation, are thought to be one major cause of carcinogenesis. However, other obesity-related factors including insulin, adipocytokines such as leptin and adiponectin, as well as inflammatory markers such as C-reactive protein and interleukins may contribute [5].

\section{The Role of Physical Activity in Breast Cancer}

Several mostly observational studies have evaluated the influence of lifestyle intervention on carcinogenesis and prevention of recurrence and mortality. A total of 110,599 women aged between 20 and 79 years were followed in the California Teachers Study [6]. A protective role of physical activity against invasive and in situ breast cancer is supported by this trial. Women who reported long-term strenuous activity of more than $5 \mathrm{~h}$ per week had a significantly reduced risk for both invasive breast cancer (relative risk (RR) 0.80 ; $95 \%$ confidence interval (CI) $0.69-0.94 ; p=0.02$ ), and in situ breast cancer $(\mathrm{RR} 0.69 ; 95 \%$ CI $0.48-0.98 ; \mathrm{p}=0.04)$. This risk reduction was observed for estrogen receptor (ER)-negative $(\mathrm{p}=0.003)$ but not ER-positive $(\mathrm{p}=0.53)$ invasive breast cancer.

Physical activity seems also to protect women who were already diagnosed with breast cancer. The Nurses' Health Study, a prospective observational study, evaluated the role of physical activity for disease recurrence and mortality [7]. Physical activity in this trial was measured as metabolic equivalent task (MET) hours per week with 3 MET hours being equivalent to $1 \mathrm{~h}$ of walking at $3-5 \mathrm{~km} / \mathrm{h}$. Compared with women who engaged in less than 3 MET hours per week, the adjusted relative risk of death from breast cancer was 0.80 (95\% CI 0.60-1.06) for 3-8.9 MET hours per week, 0.50 (95\% CI 0.31-0.82) for 9-14.9 MET hours per week, 0.56 (95\% CI 0.38-0.84) for 15-23.9 MET hours per week, and $0.60(95 \%$ CI $0.40-0.89)$ for 24 or more MET hours per week $(p=0.004)$. The benefit of physical activity was particularly apparent among women with hormone-responsive tumors, and reduction in mortality highest with $6 \%$ at 10 years for women who were physically active for $3-5 \mathrm{~h}$ a week.

\section{The Influence of Nutrition on Breast Cancer}

While only observational studies are available on physical activity, two prospectively randomized trials have been published on nutrition-based lifestyle intervention. Chlebowski et al. [8] reported the results of the Women's Intervention Nutrition Study (WINS). In this randomized controlled intervention study, postmenopausal women with early stage breast cancer were advised to reduce dietary fat intake to approximately $15-20 \%$ of their total energy intake. Women in the dietary intervention group successfully lowered fat intake ( 33.3 vs. $51.3 \%$ in the control group), but also showed significant weight loss compared to the control group (relative difference of $2.3 \mathrm{~kg}$ at year 1 and $2.7 \mathrm{~kg}$ at year $5, \mathrm{p}<0.05$ ). The hazard ratio for cancer recurrence in the intervention vs. the control group was 0.76 (95\% CI $0.60-0.98 ; \mathrm{p}=0.034)$. The lifestyle intervention tended to have a greater effect on women with hormone receptor-negative breast cancer (hazard ratio $(\mathrm{HR})=0.58 ; 95 \% \mathrm{CI} 0.37-0.91)$, but there was also a modest benefit for those with hormone receptor-positive breast cancer $(\mathrm{HR}=0.85 ; 95 \%$ CI 0.63-1.14).

In the Women's Healthy Eating and Living (WHEL) trial, women with early-stage breast cancer were randomized to receive active intervention consisting of a reduction in fat intake to $15-20 \%$ (total fat intake) and an increased intake of vegetables and fruit compared to a control group without intervention. After a mean follow-up of 7.3 years, there was no difference in recurrent breast cancer events and death indicating that a diet that was very high in vegetables, fruit and fiber and low in fat does not reduce breast cancer events or mortality. In contrast to the WINS trial, there was a modest increase in 
body weight in both groups $(0.7 \mathrm{~kg}$ in the intervention group vs. $0.3 \mathrm{~kg}$ in the control group at year 6) and there was only a modest decrease in fat intake in the intervention group (28.5\% at baseline, $22.7 \%$ at year 1 , and $28.9 \%$ at year 6 ) [9].

\section{The SUCCESS C Study}

The lack of data in the field of lifestyle intervention warrants further investigation of the effect of diet and physical activity on the prognosis of breast cancer patients. In 2009, the SUCCESS Study Group therefore initiated the SUCCESS C trial, to our knowledge the only recruiting trial evaluating a lifestyle intervention program. The aim of the trial was to evaluate the role of anthracycline-free chemotherapy treatment in a Her2/neu-negative breast cancer patient population. The second randomization addresses the role of lifestyle intervention on the prognosis of early breast cancer patients. SUCCESS C is a German multicenter, $2 \times 2$ factorial design, randomized phase III study comparing disease-free survival after randomization in patients treated with 3 cycles of FEC (epirubicine, fluorouracil, cyclophosphamide) chemotherapy, followed by 3 cycles of docetaxel (D) versus 6 cycles of docetaxel-cyclophosphamide (DC), and to compare the disease-free survival in patients with a BMI of $24-40 \mathrm{~kg} / \mathrm{m}^{2}$ after randomization to with vs. without intensive lifestyle intervention. Patients will be required to have histopathological proof of a Her2/neu-negative tumor and: axillary lymph node metastases $\left(\mathrm{pN}_{1-3}\right)$ or high-risk node-negative (defined as $\mathrm{pT} \geq 2$ or histopathological grade 3 or age $\leq 35$ or negative hormone receptor status), but are not allowed to have evidence of distant disease. In addition to the treatment intervention, the translational research program of the trial tries to identify prognostic and predictive markers that can be used to further individualize therapy in early breast cancer (fig. 1).

\section{Anthracycline-Based Chemotherapy Treatment in Early Breast Cancer}

For patients with an increased risk for recurrence, several randomized studies and the 2000 Oxford overview confirm that anthracycline-based chemotherapy offers a significant survival benefit compared with CMF (cyclophosphamide, methotrexate, 5-fluorouracil) [10-13]. The meta-analysis of the Early Breast Cancer Trialists' Collaborative Group estimates a recurrence-free survival benefit of $3.2 \%$ and an overall survival benefit of $2.7 \%$ for anthracycline-based multiagent chemotherapy compared to CMF [14].

However, the role of antracyclines in adjuvant breast cancer treatment has been increasingly questioned with regard to an appropriate risk-benefit evaluation within the last years $[15,16]$. It is particularly the late and life-threatening cardiotoxicity that remains clinically important and compromises

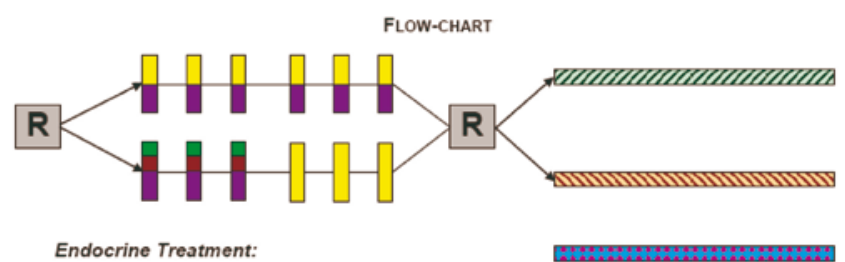

Endocrine Treatment:
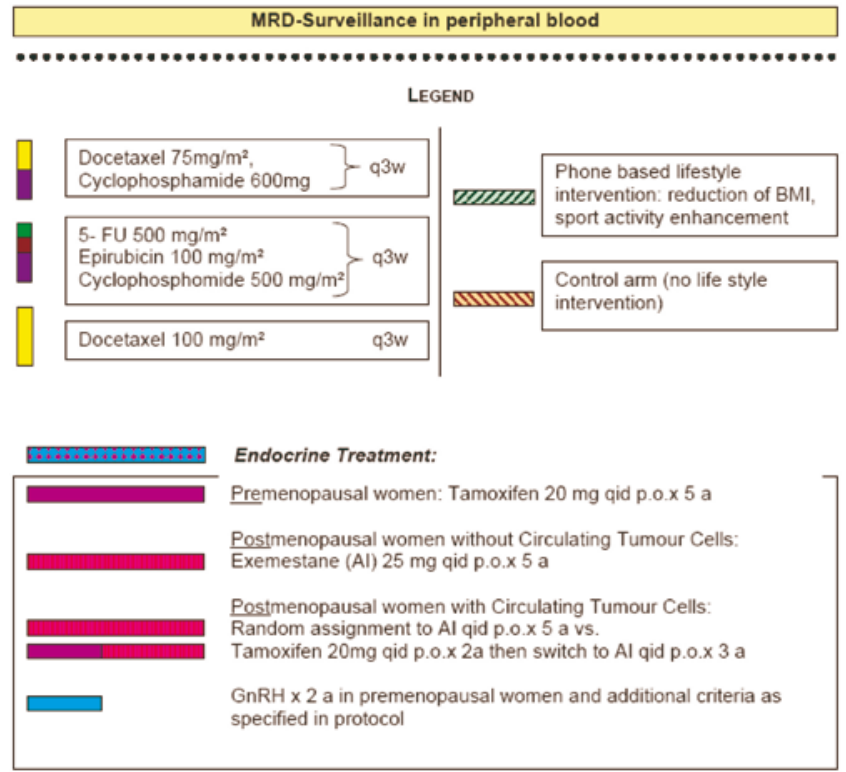

Fig. 1. SUCCESS C study design.

the role of anthracyclines, leading to late-onset cardiac dysfunction and heart failure beside the immediate toxicity associated with cardiac and hematologic effects. Especially in view of new targeted agents being implemented into clinical treatment protocols, cardiotoxicity is regarded as a relevant issue due to diminished cardiac recovery observed with these agents.

In 2006, Slamon et al. [17] presented a retrospective analysis based on BCIRG 006 data showing that the benefit of adjuvant anthracycline therapy is limited to those patients who are Her2/neu-positve, and in particular to patients with coamplification of the Her2/neu gene and the topoisomerase 2 alpha gene. Another more recent analysis by Gennari et al. [18] confirmed these findings after pooling data from 8 studies and comparing non-anthracycline-based adjuvant chemotherapy (mainly CMF) with anthracycline-containing combinations. For Her2/neu-positive tumors $(29 \%, n=1,536)$, anthracycline-based regimens were superior to non-anthracycline-based regimens in terms of disease-free survival and overall survival (HR of relapse 0.71 and death 0.73 ). For Her2/neu-negative tumors (remaining 3,818 patients), anthracyclines did not improve disease-free survival and overall survival ( $\mathrm{HR}=1.0 ; \mathrm{HR}=1.03$, respectively) (fig. 2). Based on a retrospective analysis of the MA 05 trial testing CMF versus Canadian FEC in 710 node-positive $(\mathrm{N}+)$ premenopausal 


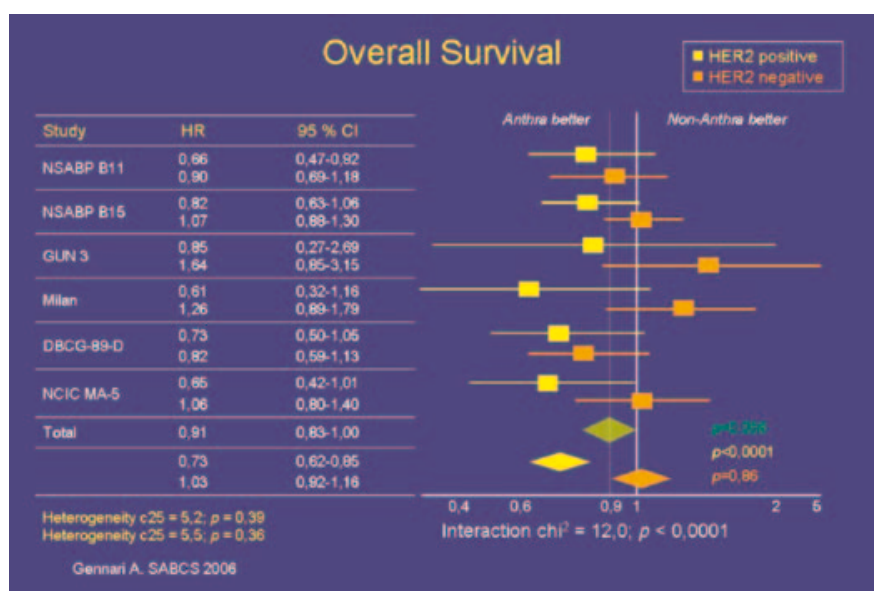

Fig. 2. Meta-analysis of anthracycline-efficacy in relation to HER2/neu status.

patients, clinical routine Her2/neu status determination is being regarded as a good predictor of an anthracycline response [19]. These results suggest that Her2/neu-negative patients might have only limited benefit from anthracyclinebased chemotherapy, especially in view of the cardiac side effects. Thus it seems crucial to identify those subgroups of breast cancer patients in which the expected benefits are most likely to outweigh known risks, and confine anthracycline treatment to these.

Further support for anthracycline-free adjuvant chemotherapy comes from a randomized phase III trial by Jones et al. [20] for the US Oncology Group. A total of 1,016 high-risk node-negative $(\mathrm{N}-)$ and $\mathrm{N}+$ breast cancer patients received either 4 cycles of doxorubicin $\left(60 \mathrm{mg} / \mathrm{m}^{2}\right)$ plus cyclophosphamide $\left(600 \mathrm{mg} / \mathrm{m}^{2}\right)(\mathrm{AC})$ every 3 weeks $(\mathrm{q} 3 \mathrm{w})$ or 4 cycles of docetaxel $\left(75 \mathrm{mg} / \mathrm{m}^{2}\right)$ plus cyclophosphamide $\left(600 \mathrm{mg} / \mathrm{m}^{2}\right)$ (TC) q3w. The results were in favor of TC, showing diseasefree survival of 86 vs. $80 \%(p=0.01)$ and overall survival of 90 vs. $87 \%(\mathrm{p}=0.13)$. The update with an extended 7-year follow-up further supports the advantage of TC with a disease-free survival of 81 vs. $75 \%(p=0.033)$ and overall survival of 87 vs. $82 \%(p=0.032)$ [21]. Despite this promising results, 4 cycles of AC can not be accepted as adequately dosed standard treatment in early breast cancer. The evaluation of anthracycline-free regimens against modern sequential anthracycline-taxane-based regimens in several open trials reflects the interest in this clinically relevant question. In the German Plan B trial, 6 cycles of TC are tested against 4 cycles of EC followed by 4 cycles of docetaxel. The SUCCESS C trial will compare the disease-free survival after randomization in patients treated with 3 cycles of FEC (epirubicine $100 \mathrm{mg} / \mathrm{m}^{2}+$ fluorouracil $500 \mathrm{mg} / \mathrm{m}^{2}+$ cyclophosphamide $500 \mathrm{mg} / \mathrm{m}^{2}$ ), followed by 3 cycles of D (docetaxel $100 \mathrm{mg} / \mathrm{mg}^{2}$ ) versus 6 cycles of DC (cyclophosphamide $600 \mathrm{mg} / \mathrm{m}^{2} \mathrm{q} 3 \mathrm{w}+$ docetaxel $75 \mathrm{mg} / \mathrm{m}^{2}$ ).
The Lifestyle Intervention Program within SUCCESS C

The second objective of the study will be to evaluate the efficacy of a lifestyle intervention program to improve diseasefree survival in early breast cancer. Patients with a BMI of $24-40 \mathrm{~kg} / \mathrm{m}^{2}$ at the time of enrollment will be subsequently randomized to a lifestyle intervention program versus observation. Women randomized to the intervention arm will receive a standardized individualized intervention program for the duration of 2 years designed to promote weight loss over the first 6 months followed by weight loss maintenance. The predefined treatment goals are: i) weight loss of $5-10 \%$ of baseline weight but not below a BMI of $22 \mathrm{~kg} / \mathrm{m}^{2}$, at least $5 \%$ in those with a BMI between 24 and $30 \mathrm{~kg} / \mathrm{m}^{2}$, and $10 \%$ in those with a BMI $\geq 30 \mathrm{~kg} / \mathrm{m}^{2}$; ii) caloric deficit of $500-1,000$ $\mathrm{kcal} /$ day based on current weight and weight loss goals; iii) fat intake of less than $20-25 \%$ of the total energy intake; iv) progressive physical activity depending on baseline activity; gradual increase to 150-200 min of moderate physical activity per week; pedometers will be distributed to support the intended step-wise increase in physical activity.

The key elements of the intervention are the following: i) A hypocaloric diet with an estimated energy deficit of 500$1,000 \mathrm{kcal} /$ day which is mainly based on fat reduction to 20 $25 \%$ of the total energy intake. In parallel, the intake of wholegrain products, fruit and vegetables should be increased. The level of caloric intake will be between 1,200 and 1,800 $\mathrm{kcal} /$ day according to the individual goals. Adaptations are possible during the course of the intervention to achieve the weight goals. ii) A gradual increase in physical activity. The preferred recommendation is a moderate intensity aerobic physical activity such as brisk walking between 150 and 200 min per week, coupled with resistance and stretching exercises. iii) Individual lessons in behavioral and motivational issues including relapse prevention, reduction in emotional distress, overcoming barriers.

The intervention will be provided by a personal lifestyle coach working in a central call center. This coaching team consists of trained nurses, dieticians, physicians, and psychologists. A series of semi-structured telephone calls will build the core of the active intervention, supplemented with a detailed participant workbook and regular newsletters. Women will be encouraged to start with the diet and the increase in physical activity as quickly as possible to reach their weight loss goal within 6 months and then, to maintain this weight loss.

As weight loss is the main goal of the life style intervention, normal weight or underweight patients $(\mathrm{BMI}<24)$ are excluded from this randomization. In these patients, further weight loss might even have a negative effect on their general health as well as on breast cancer prognosis. On the other hand, extreme obesity in overweight patients with a BMI $>40$ is associated with an increased risk of chronic diseases, and these women were not thought to be able to participate in our telephone-based intervention program. Patients randomized 
to the control arm or with a BMI $<24 \mathrm{~kg} / \mathrm{m}^{2}$ or $>40 \mathrm{~kg} / \mathrm{m}^{2}$ will be mailed information on general health after completion of chemotherapy and at 1 year. Participants in the control group will additionally receive a 2 -year free subscription to a lifestyle magazin.

\section{Translational Research Program}

The aim of the translational research program is to identify prognostic and predictive markers that can be used to further individualize therapy in early breast cancer. It is planned to measure obesity-related biomarkers like fasting insulin and adiponectin and potentially other upcoming adipokines of interest to test the prognostic and predictive value of these markers in the context of the intervention program. Additionally, genetic variations in germline DNA and tumor DNA will be compared with the phenotype of the tumor and the efficacy and side effects of chemotherapy. This should result in a biomarker panel which comprises the patients' DNA and tumor material to individualize the choice for or against a therapy with anthracyclines.

The detection of circulating tumor cells (CTCs) in the peripheral blood will also be an integral part of the research program. Based on the promising results of the predecessor trial, the SUCCESS A trial, which indicated a prognostic relevance of CTCs [22], an endocrine treatment randomization will be performed. CTC-positive, hormone receptor-posi-

\section{Postmenopausal women without} Circulating Tumour Cells:

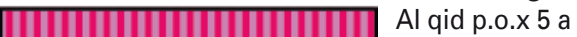

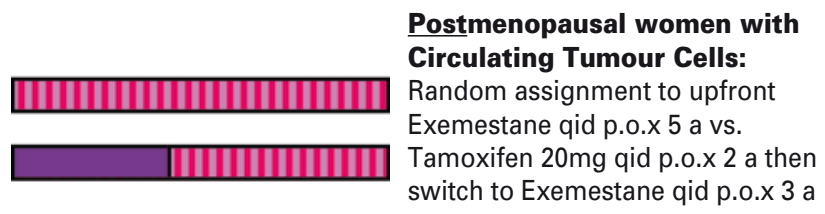

Fig. 3. Endocrine treatment for postmenopausal hormone receptorpositive women. tive, postmenopausal patients will be entered into a treatment substudy, randomizing between tamoxifen for 2-3 years followed by exemestane (early switch) vs. exemestane upfront. All patients will be followed with a subsequent blood test after 2 years and, if applicable, in the case of recurrence (fig. 3). This subprotocol of the Success $\mathrm{C}$ trial will provide additional information on whether CTCs can be used as a prognostic factor for an adverse outcome as well as a predictive marker for endocrine treatment efficacy.

\section{Conclusion}

There is conclusive epidemiological data suggesting an important role of obesity and lifestyle factors on carcinogenesis and survival after breast cancer diagnosis. The prospectively randomized SUCCESS C trial will provide information on whether lifestyle modification focusing on a fat-reduced healthy diet and moderate physical activity is able to improve the prognosis of breast cancer patients. Additionally, the efficacy of anthracycline-free treatment regimen in Her2/neu-negative breast cancer patients will be evaluated. The translational research program of the trial will aim to identify prognostic and predictive markers which can help to further individualize breast cancer treatment.

\section{Acknowledgements}

This study is supported by unrestricted grants from Pfizer, SanofiAventis, Chugai, and Veridex.

\section{Conflict of Interest}

Brigitte Rack, Harald Sommer, Werner Lichtenegger, Klaus Friese, and Matthias W. Beckmann have received research funding and speakers honoraria from Pfizer, Sanofi-Aventis, and Chugai. Brigitte Rack and Wolfgang Janni have received research funding and speakers honoraria from Veridex. Philipp Hepp has received speakers honoraria from Chugai. Ulrich Andergassen, Julia Neugebauer, Jessica Salmen, Hans Hauner, and Dagmar Hauner have no conflicts of interest to declare.

\section{References}

1 Ferlay J, Parkin DM, Steliarova-Foucher E: Estimates of cancer incidence and mortality in Europe in 2008. Eur J Cancer 2010;46:765-781.

$>2$ Reeves GK, Pirie K, Beral V, Green J, Spencer E, Bull D: Cancer incidence and mortality in relation to body mass index in the Million Women Study: cohort study. BMJ 2007;335:1134.

3 Chen X, Lu W, Zheng W, Gu K, Chen Z, Zheng $\mathrm{Y}$, Shu XO: Obesity and weight change in relation to breast cancer survival. Breast Cancer Res Treat 2010;122:823-833.
4 Chlebowski RT, Aiello E, McTiernan A: Weight loss in breast cancer patient management. J Clin Oncol 2002;20:1128-1143.

5 Goodwin PJ, Pritchard KI: Obesity and hormone therapy in breast cancer: an unfinished puzzle. J Clin Oncol 2010;\%20;28:3405-3407.

6 Dallal CM, Sullivan-Halley J, Ross RK, Wang Y, Deapen D, Horn-Ross PL, Reynolds P, Stram DO, Clarke CA, Anton-Culver H, Ziogas A, Peel D, West DW, Wright W, Bernstein L: Long-term recreational physical activity and risk of invasive and in situ breast cancer: the California Teachers study. Arch Intern Med 2007;167:408-415.
7 Holmes MD, Chen WY, Feskanich D, Kroenke CH, Colditz GA: Physical activity and survival after breast cancer diagnosis. JAMA 2005;293:2479-2486.

8 Chlebowski RT, Blackburn GL, Thomson CA, Nixon DW, Shapiro A, Hoy MK, Goodman MT, Giuliano AE, Karanja N, McAndrew P, Hudis C, Butler J, Merkel D, Kristal A, Caan B, Michaelson R, Vinciguerra V, Del Prete S, Winkler M, Hall R, Simon M, Winters BL, Elashoff RM: Dietary fat reduction and breast cancer outcome: Interim efficacy results from the Women's Intervention Nutrition Study. J Natl Cancer Inst 2006;98:1767-1776. 


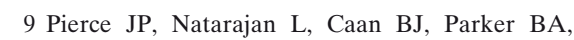
Greenberg ER, Flatt SW, Rock CL, Kealey S, Al Delaimy WK, Bardwell WA, Carlson RW, Emond JA, Faerber S, Gold EB, Hajek RA, Hollenbach K, Jones LA, Karanja N, Madlensky L, Marshall J, Newman VA, Ritenbaugh C, Thomson CA, Wasserman L, Stefanick ML: Influence of a diet very high in vegetables, fruit, and fiber and low in fat on prognosis following treatment for breast cancer - The Women's Healthy Eating and Living (WHEL) Randomized Trial. JAMA 2007;298:289_ 298.

10 Early Breast Cancer' Collaborative Group. Analysis overview results. 21-9-2000. Oxford, 5th Meeting of the Early Breast Trialists' Collaborative Group.

11 Levine MN, Bramwell VH, Pritchard KL, Norris B, Shepherd LE, Abu ZH, Findlay B, Warr D, Bowman D, Myles J, et al.: Randomized trial of intensive cyclophosphamide, epirubicin, and fluorouracil chemotherapy compared with cyclophosphamide, methotrexate, and fluorouracil in premenopausal women with node-positive breast cancer. National Cancer Institute of Canada Clinical Trials Group. J Clin Oncol 1998;16:2651-2658.

-12 Coombes RC, Bliss JM, Wils J, Morvan F, Espie M, Amadori D, Gambrosier P, Richards M, Aapro M, Villar-Grimalt A, McArdle C, Perez-Lopez FR, Vassilopoulos P, Ferreira EP, Chilvers CE, Coombes G, Woods EM, Marty M: Adjuvant cyclophosphamide, methotrexate, and fluorouracil versus fluorouracil, epirubicin, and cyclophosphamide chemotherapy in premenopausal women with axillary node-positive operable breast cancer: results of a randomized trial. The International Collaborative Cancer Group. J Clin Oncol 1996;14:35-45.
13 Fisher B, Brown AM, Dimitrov NV, Poisson R, Redmond C, Margolese RG, Bowman D, Wolmark N, Wickerham DL, Kardinal CG: Two months of doxorubicin-cyclophosphamide with and without interval reinduction therapy compared with 6 months of cyclophosphamide, methotrexate, and fluorouracil in positive-node breast cancer patients with tamoxifen-nonresponsive tumors: results from the National Surgical Adjuvant Breast and Bowel Project B-15. J Clin Oncol 1990;8:1483-1496.

14 EBCTCG: Polychemotherapy for early breast cancer: an overview of the randomised trials. Early Breast Cancer Trialists' Collaborative Group. Lancet 1998;352:930-942.

15 Bird BR, Swain SM: Cardiac toxicity in breast cancer survivors: review of potential cardiac problems. Clin Cancer Res 2008;14:14-24.

16 Gianni L, Herman EH, Lipshultz SE, Minotti G, Sarvazyan N, Sawyer DB: Anthracycline cardiotoxicity: from bench to bedside. J Clin Oncol 2008:26:3777-3784

17 Slamon D, Eiermann W, Robert N, Pienkowski T, Martin M, Pawlicki M, Chan A, Smylie M, Liu M, Falkson C, Pinter T, Fornander T, Shiftan T, Valero V, Von Minckwitz G, Mackey J, TabahFisch I, Buyse M, Lindsay MA, Riva A, Bee V, Pegram M, Press M, Crown J: Breast Cancer Res Treat 2006;100(suppl 1):abstr 52.

18 Gennari A, Sormani MP, Pronzato P, Puntoni M, Colozza M, Pfeffer U, Bruzzi P: HER2 status and efficacy of adjuvant anthracyclines in early breast cancer: a pooled analysis of randomized trials. J Natl Cancer Inst 2008;100:14-20.
19 Pritchard KI, Shepherd LE, O'Malley FP, Andrulis IL, Tu D, Bramwell VH, Levine MN: HER2 and responsiveness of breast cancer to adjuvant chemotherapy. N Engl J Med 2006;354:2103-2111.

20 Jones SE, Savin MA, Holmes FA, O'Shaughnessy JA, Blum JL, Vukelja S, McIntyre KJ, Pippen JE, Bordelon JH, Kirby R, Sandbach J, Hyman WJ, Khandelwal P, Negron AG, Richards DA, Anthony SP, Mennel RG, Boehm KA, Meyer WG, Asmar L: Phase III trial comparing doxorubicin plus cyclophosphamide with docetaxel plus cyclophosphamide as adjuvant therapy for operable breast cancer. J Clin Oncol 2006;24:5381-5387.

21 Jones S, Holmes FA, O'Shaughnessy J, Blum JL, Vukelja SJ, McIntyre KJ, Pippen JE, Bordelon JH, Kirby RL, Sandbach J, Hyman WJ, Richards DA, Mennel RG, Boehm KA, Meyer WG, Asmar L, Mackey D, Riedel S, Muss H, Savin MA: Docetaxel with cyclophosphamide is associated with an overall survival benefit compared with doxorubicin and cyclophosphamide: 7-year follow-up of US Oncology Research Trial 9735. J Clin Oncol 2009;27:1177-1183.

22 Rack B, Schindlbeck C, Andergassen U, Schneeweiss A, Zwingers T, Lichtenegger W, Beckmann MW, Sommer H, Pantel K, Janni W: Use of circulating tumor cells (CTC) in peripheral blood of breast cancer patients before and after adjuvant chemotherapy to predict risk for relapse: The SUCCESS trial. J Clin Oncol 2010;28:15s. 